\title{
Impaired Stress-Coping and Fear Extinction and Abnormal Corticolimbic Morphology in Serotonin Transporter Knock-Out Mice
}

\author{
C. L. Wellman, ${ }^{1}$ A. Izquierdo, ${ }^{2}$ J. E. Garrett, ${ }^{1}$ K. P. Martin, ${ }^{1}$ J. Carroll, ${ }^{3}$ R. Millstein, ${ }^{2}$ K.-P. Lesch, ${ }^{4}$ D. L. Murphy, ${ }^{3}$ and \\ A. Holmes ${ }^{2}$ \\ ${ }^{1}$ Department of Psychological and Brain Sciences, Indiana University, Bloomington, Indiana 47405, ${ }^{2}$ Section on Behavioral Science and Genetics, \\ Laboratory for Integrative Neuroscience, National Institute on Alcoholism and Alcohol Abuse, National Institutes of Health, Bethesda, Maryland 20852, \\ ${ }^{3}$ Laboratory of Clinical Science, National Institute of Mental Health, National Institutes of Health, Bethesda, Maryland 20892, and ${ }^{4}$ Molecular and Clinical \\ Psychobiology, Department of Psychiatry and Psychotherapy, University of Würzburg, Würzberg 97080, Germany
}

\begin{abstract}
A lesser-expressing form of the human 5-HT transporter (5-HTT) gene has been associated with increased fear and anxiety and vulnerability to the effects of stress. These phenotypic abnormalities are linked to functional and anatomical disturbances in a neural pathway connecting the prefrontal cortex (PFC) and amygdala. Likewise, rodent and nonhuman primate studies indicate a major role for PFC and amygdala in the mediation of fear- and stress-related behaviors. We used a 5-HTT knock-out (KO) mouse to examine the effects of genetically driven loss of 5-HTT function for the following: (1) depression-related behavior in response to repeated stress, and pavlovian fear conditioning, extinction, and extinction recall; and (2) dendritic morphology and spine density of Golgi-stained pyramidal neurons in the infralimbic cortex (IL) and the basolateral amygdala (BLA). 5-HTT KO mice exhibited increased depressive-like immobility after repeated exposure to forced swim stress, compared with wild-type (WT) controls. Whereas fear conditioning and fear extinction was normal, 5-HTT KO mice exhibited a significant deficit in extinction recall. The apical dendritic branches of IL pyramidal neurons in 5-HTT KO mice were significantly increased in length relative to WT mice. Pyramidal neurons in BLA had normal dendritic morphology but significantly greater spine density in 5-HT KO mice compared with WT mice. Together, the present findings demonstrate a specific phenotypic profile of fear- and stress-related deficits in 5-HTT KO mice, accompanied by morphological abnormalities in two key neural loci. These data provide insight into the behavioral sequelae of loss of 5-HTT gene function and identify potential neural substrates underlying these phenotypes.
\end{abstract}

Key words: serotonin transporter; gene; stress; prefrontal cortex; amygdala; extinction

\section{Introduction}

Corticolimbic pathways mediating emotion are rich in 5-HT terminals and receptors (Barnes and Sharp, 1999), and both 5-HT and corticolimbic dysfunction are implicated in affective disorders (Hariri and Holmes, 2006). 5-HT neurotransmission is regulated by clearance of 5 -HT from the extracellular space by the $\mathrm{NaCl}$-dependent 5-HT transporter (5-HTT) (SERT) (Blakely et al., 1991). The 5-HTT is a principal target for antidepressants (Ballenger, 1999), and drug-free mood and anxiety disorder patients have reduced prefrontal cortex (PFC) 5-HTT binding (Arango et al., 2002). Moreover, a low-expressing polymorphism in the HTT promoter region (Lesch et al., 1996) associates with heightened fear and anxiety (Lesch et al., 1996; Bengel et al., 1998;

\footnotetext{
Received 0ct. 23, 2006; revised Nov. 28, 2006; accepted Dec. 11, 2006.

This work was supported by the National Institute on Alcohol Abuse and Alcoholism and National Institute of Mental Health Intramural Research Programs, a National Alliance for Research on Schizophrenia and Depression grant (A.H.), National Institute of Mental Health Grant MH067607 (C.L.W.), Deutsche Forschungsgemeinschaft Grant DFG SFB581, and Klinische Forschergruppen Grant KF0 125/1-1 (K.P.L.).

Correspondence should be addressed to A. Holmes at the above address. E-mail: holmesan@mail.nih.gov. DOI:10.1523/JNEUROSCI.4595-06.2007

Copyright $\odot 2007$ Society for Neuroscience $\quad 0270-6474 / 07 / 270684-08 \$ 15.00 / 0$
}

Garpenstrand et al., 2001; Munafo et al., 2005) and risk for posttraumatic stress disorder (PTSD) (Lee et al., 2005) and major depression following stress (Caspi and Moffitt, 2006).

Although these data suggest that deficits in 5-HTT function compromise stress coping, the neural basis of this effect has not been fully ascertained. The low-expressing HTT polymorphism is associated with increased amygdala activity in response to fearful stimuli and at rest (Hariri et al., 2002; Canli et al., 2006). This hyperactivation correlates with reduced volume of the anterior cingulate (ACC) region of the PFC, as well as weakened functional coupling between the ACC and amygdala (Pezawas et al., 2005) and increased activation of the ventromedial PFC (vmPFC) (Canli et al., 2005; Heinz et al., 2005; Pezawas et al., 2005).

PFC regulation of responses to emotional stimuli in human imaging studies is consistent with findings from rodent models (Cryan and Holmes, 2005). Inactivation of the infralimbic (IL) and prelimbic (PL) regions of the vmPFC induces learned helplessness behavior after exposure to uncontrollable stress because of loss of PFC inhibitory control over 5-HT responses to stress (Amat et al., 2005). The vmPFC-amygdala circuit also plays an 
integral role in the regulation of fear memory (Quirk and Beer, 2006). The vmPFC and amygdala are reciprocally innervated (Canteras et al., 1992; Bacon et al., 1996; McDonald et al., 1996; Smith et al., 2000; Berretta et al., 2005), and the vmPFC likely participates in modulation of learned fear via input to amygdaloid nuclei (Sotres-Bayon et al., 2004), perhaps by activation of inhibitory neurons in the intercalated nuclei (Berretta et al., 2005). Lesions (Quirk et al., 2000), neurochemical inactivation (Santini et al., 2001; Santini et al., 2004), or stress-induced dendritic retraction in this region produces deficits in fear extinction and/or the recall of extinction (Izquierdo et al., 2006; Miracle et al., 2006) resulting from dysregulation of PFC modulation of the amygdala (Canteras et al., 1992; McDonald et al., 1996; Smith et al., 2000; Berretta et al., 2005). These effects are localized to neurons in the IL (Milad and Quirk, 2002).

Here, we used a 5-HTT knock-out (KO) mouse model (Bengel et al., 1998) to further evaluate the consequences of disruption of 5-HTT function for corticolimbic neuronal morphology and stress- and fear-related behaviors mediated by this circuit. This model has previously provided insight into the consequences of loss of 5-HTT gene function for emotion-related behaviors and for cortical development (Esaki et al., 2005; Hariri and Holmes, 2006; Li, 2006). First, we tested for depression-related behavior and pavlovian fear conditioning, extinction, and extinction recall. Next, we assessed dendritic morphology and spine density of pyramidal neurons in IL and basolateral amygdala.

\section{Materials and Methods}

Animals. 5-HTT KO mice were generated as described previously by replacing a $1.1 \mathrm{kbp}$ fragment of the $\mathrm{htt}$ gene containing exon 2 with a 1.8 kbp pPNT-neo replacement targeting vector (Bengel et al., 1998). Mice originally from a 129P1 $(129 \mathrm{P} 1 / \mathrm{ReJ}) \times \mathrm{C} 57 \mathrm{BL} / 6 \mathrm{~J}$ hybrid genetic background were repeatedly backcrossed onto a C57BL/6J for more than eight generations. Male 5-HTT KO mice and nonmutant wild-type (WT) controls were siblings derived from matings between 5-HTT heterozygous parents. Male nonmutant C57BL/6J mice used to assess the effects of fluoxetine in the repeated forced swim test (FST) procedure (see below) were obtained from The Jackson Laboratory (Bar Harbor, ME) at $8-10$ weeks of age and tested $\sim 1$ week later. All mice were housed (two to five per cage) in same-sex littermate groups in a temperature- and humidity-controlled vivarium under a $12 \mathrm{~h}$ light/dark cycle (lights on at 6:00 A.M.). Before testing, mice were given a $1 \mathrm{~h}$ acclimation period in the testing room. Experimenters remained blind to experimental variables during testing. Experimental procedures were performed in strict accordance with the National Institutes of Health Guide for Care and Use of Laboratory Animals and were approved by the local Animal Care and Use Committee.

Repeated forced swim stress. Sixteen 5-HTT KO mice and 15 WT mice were assessed for depression-related behavior using a modified version of the mouse forced swim test in which subjects were repeatedly exposed to the swim stressor (Porsolt et al., 1977). On day 1, mice received a single 15 min FST exposure to a $25-\mathrm{cm}$-high, 20-cm-diameter cylinder filled with $24 \pm 1{ }^{\circ} \mathrm{C}$ water, as described previously (Boyce-Rustay and Holmes, 2006). On day 2 , mice received four consecutive 6 min exposures with a 12-15 min intertrial interval between trials. Passive immobility (cessation of movement except minor involuntary movements of the hindlimbs) was measured using an instantaneous sampling method every $5 \mathrm{~s}$ during minutes $2-6$ on each day by an observer blind to genotype and converted to a percentage of observations [(freezing observations/total observations) $\times 100]$.

A separate experiment was conducted to confirm that both acute and repeated exposure to the test were sensitive to a pharmacological manipulation known to produce alterations in depression-related behavior in the forced swim test in nonmutant mice. This would argue against the possibility that genotype differences during repeated but not acute exposure were an artifact of a relative insensitivity of the former to experimen-

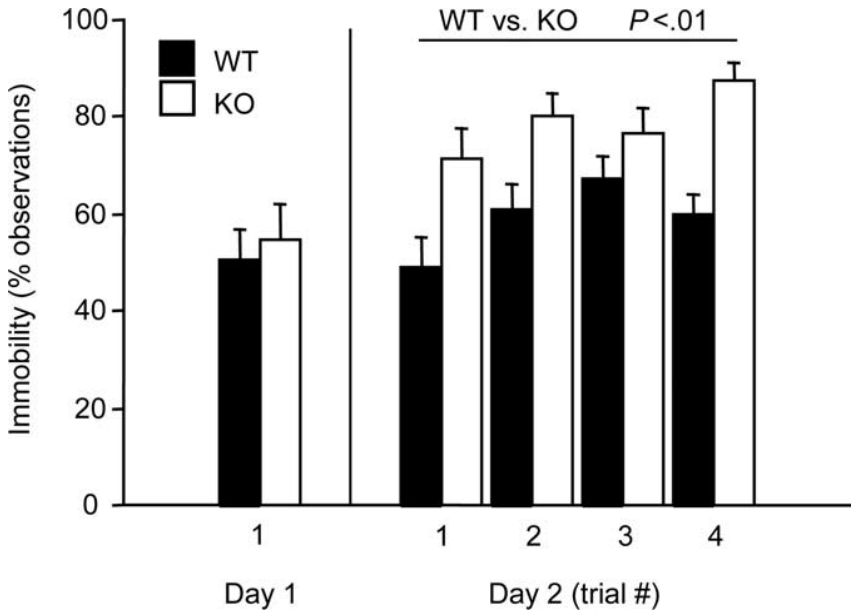

Figure 1. Increased depression-like behavior during repeated stress in 5-HTT K0 mice. 5-HTT KO mice showed significantly increased depression-related behavior in response to repeated forced swimming. Data are mean \pm SEM percentage observations of immobility $(n=$ 15-16/genotype).

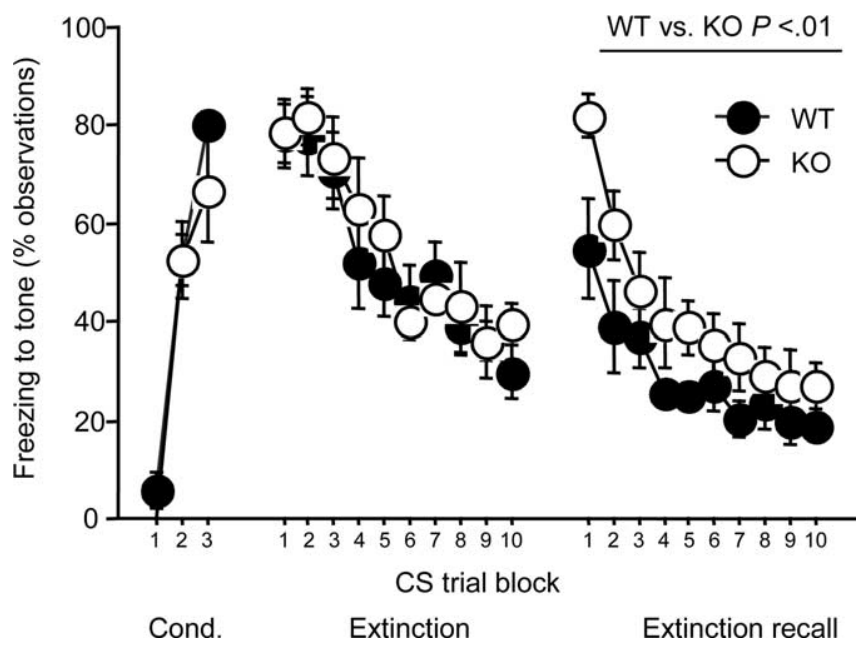

Figure 2. Impaired extinction recall in 5-HTT K0 mice. 5-HTT KO mice showed normal conditioning (Cond.), CS-recall, and extinction of a conditioned fear response but exhibited significantly impaired extinction recall compared with WT mice. Data are mean \pm SEM percentage observations of freezing during $\mathrm{C} S$ trial blocks ( $n=6 /$ genotype).

tal manipulation. Male C57BL/6J mice were assessed on 6 min FST exposure $30 \mathrm{~min}$ after intraperitoneal injection (at a volume of $10 \mathrm{ml} / \mathrm{kg}$ body weight) of $0,5,10$, or $20 \mathrm{mg} / \mathrm{kg}$ fluoxetine hydrochloride (Sigma, St. Louis, MO) dissolved in $0.9 \%$ saline. Half of the mice were FST-naive, whereas the other half had received a 15 min FST exposure $24 \mathrm{~h}$ earlier. Doses were chosen on the basis of previously demonstrated antidepressant-related effects of fluoxetine in C57BL/6 $\mathrm{J}$ mice (Holmes et al., 2002).

Pavlovian fear conditioning, extinction, and extinction recall. An experimentally naive cohort of eight 5-HTT KO and nine WT mice were tested for fear conditioning, extinction, and extinction recall using methods based on those described previously (Cain et al., 2002; Izquierdo et al., 2006). Conditioning was conducted in a $27 \times 27 \times 11 \mathrm{~cm}$ chamber with transparent walls and a metal rod floor, cleaned with a $79.5 \%$ water/ $19.5 \%$ ethanol $/ 1 \%$ vanilla-extract solution. After a $120 \mathrm{~s}$ acclimation period, mice received three pairings (60-120 s variable interpairing interval) of the conditioned stimulus (CS) $(30 \mathrm{~s}, 80 \mathrm{~dB}, 3 \mathrm{kHz}$ tone) and the unconditioned stimulus (US) ( $2 \mathrm{~s}, 0.6 \mathrm{~mA}$ scrambled footshock), in which the US was presented during the last $2 \mathrm{~s}$ of the CS by the San Diego Instruments (San Diego, CA) Freeze Monitor system. After a 120 s no- 
stimulus consolidation period after the final CS-US pairing, mice were returned to the home cage.

Twenty-four hours later, initial CS-recall and subsequent CS-extinction was measured in a novel context (black/white-checkered walls and a solid-Plexiglas, opaque floor, cleaned with a $50 \%$ ethanol $/ 50 \%$ water solution) housed in a different room from that used for conditioning. After a $120 \mathrm{~s}$ acclimation period, the mouse received forty $30 \mathrm{~s}$ CS presentations (5 s interstimulus interval). The same procedure was repeated $24 \mathrm{~h}$ later to assess extinction recall.

Freezing (no visible movement except respiration) was scored using an instantaneous sampling method every $5 \mathrm{~s}$ by an observer blind to genotype and converted to a percentage of observations [(freezing observations/total observations $) \times 100]$. Freezing was averaged over each CS trial during conditioning and averaged into four-trial blocks during freezing extinction and extinction recall.

Histology and morphological analyses. Dendritic and spine analyses were performed on mice at the completion of fear conditioning/ extinction/recall. Mice used for forced swim testing were not used for morphological analysis as we have shown previously that this procedure causes dendritic alterations of the PFC of nonmutant mice (Izquierdo et al., 2006). Within $1 \mathrm{~h}$ of the completion of extinction recall testing, five 5-HTT KO and six WT mice were overdosed with isoflurane and transcardially perfused with saline. Brains were removed and processed for Golgi histology using Glaser and Van der Loos' modified Golgi stain (Glaser and Van der Loos, 1981). Briefly, tissue was immersed in Golgi-Cox solution for $10 \mathrm{~d}$. Brains were then dehydrated, infiltrated with a graded series of celloidins, and embedded in $8 \%$ celloidin. Coronal sections were cut at $200 \mu \mathrm{m}$ on a sliding microtome (Leica Histoslide 2000; Leica, Nussloch, Germany). Freefloating sections were then alkalinized, developed in Kodak (Rochester, NY) D-19, fixed in Kodak Rapid Fix (solution B omitted), dehydrated, mounted, and coverslipped.

IL was identified by its position on the medial wall of the rostral cortex, its location ventral to PL, and its characteristic cytoarchitecture: IL is markedly thinner than prelimbic cortex and has fewer, less well-defined layers (Paxinos and Franklin, 2001). Basolateral amygdala (BLA) analysis was restricted to pyramidal neurons located between 8.0 and $2.0 \mathrm{~mm}$ posterior to bregma. Within this region, BLA is readily identified in Golgi-stained material, as the external capsule branches into two smaller fiber tracts that define the dorsal, medial, and lateral borders of the BLA. Likewise, axon fibers clearly delineate basal amygdala from BLA. Pyramidal neurons within IL and BLA were defined by the presence of a distinct, single apical dendrite (for IL, extending from the apex of the soma toward the pial surface of the cortex), two or more basilar dendritic trees extending from the base of the soma, and dendritic spines (see Figs. $3 a, 6 a)$.

Dendritic analyses. Neurons selected for reconstruction were located in the middle third of the section, did not have truncated branches, and were unobscured by neighboring neurons and glia, with dendrites that were easily discriminable by focusing through the depth of the tissue. Within each region examined, $8-11$ neurons were drawn for each mouse; this number yielded an average within-animal error for total dendritic length of $\sim 12.1 \pm 0.5 \%$ for IL neurons and $\sim 9.2 \pm 0.6 \%$ for BLA neurons. Neurons were drawn at $400-600 \times$, and morphology of apical and basilar arbors was quantified in three dimensions using a computerbased neuron tracing system (Neurolucida; MBF Bioscience, Williston, VT) (for IL, see Fig. $3 a$; for BLA, see Fig. $6 a$ ) with the experimenter blind to genotype. To rule out artifactual differences in dendritic morphology
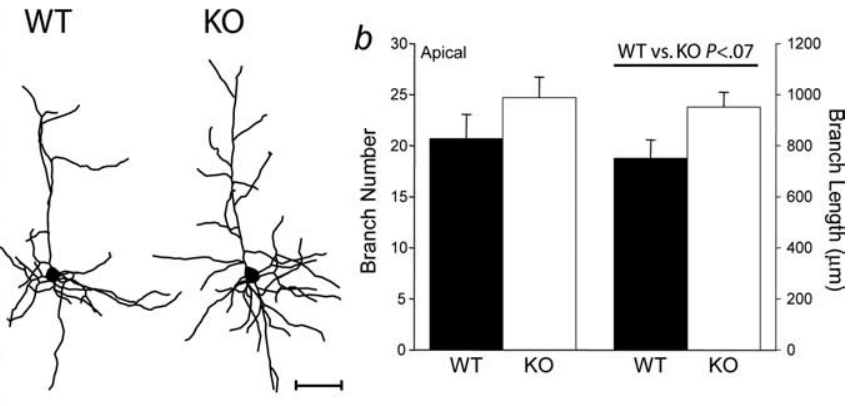

d

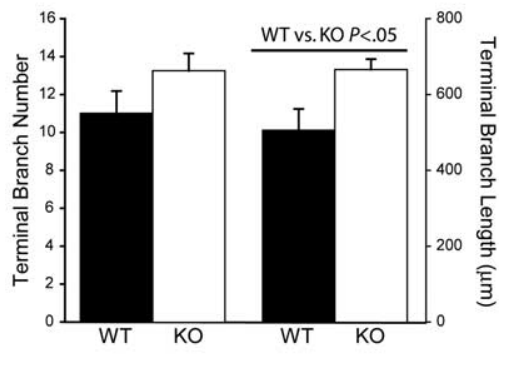

Distance from Soma $(\mu \mathrm{m})$ 

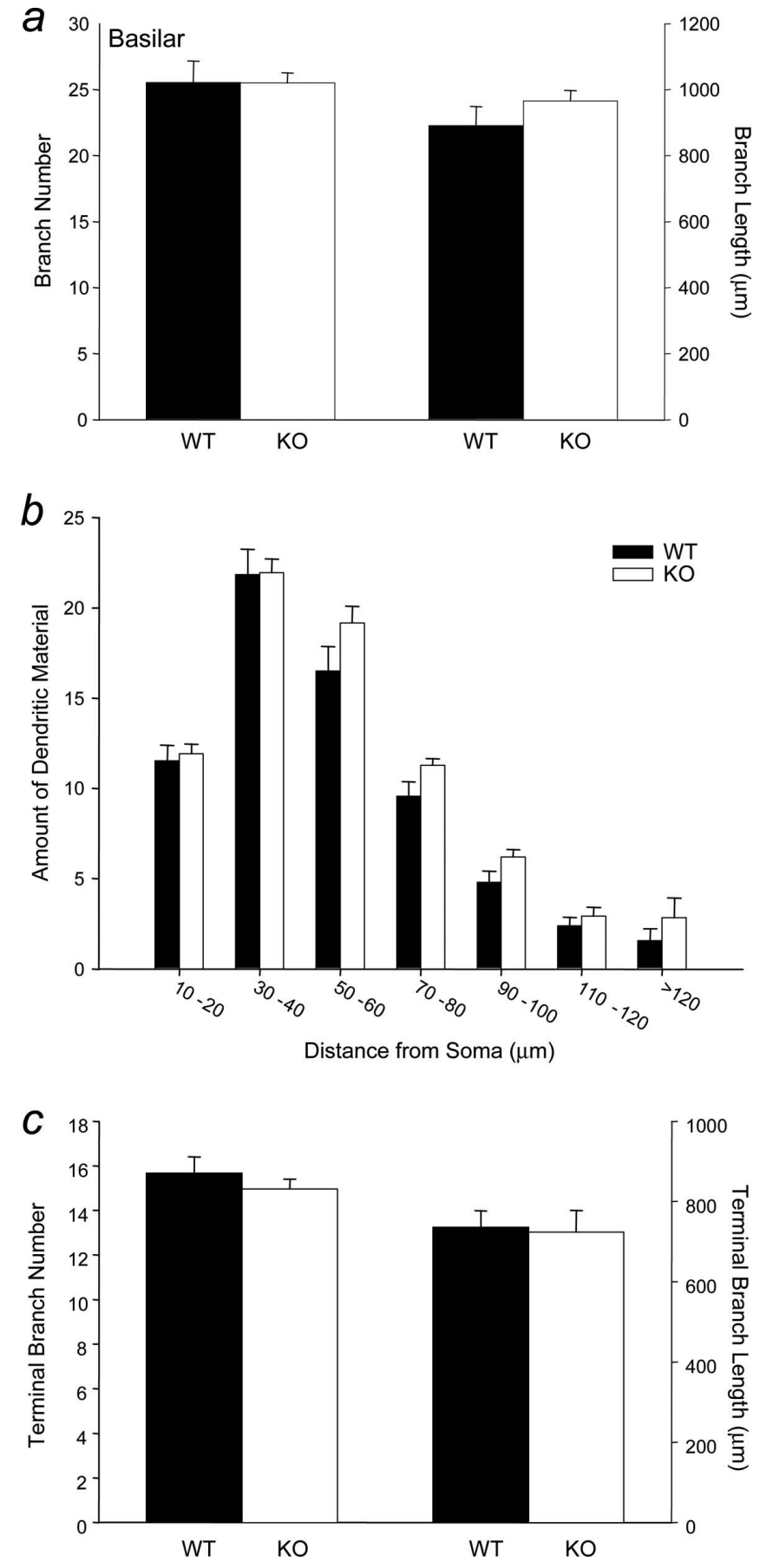

Figure 4. Normal basilar dendritic morphology of IL pyramidal neurons in 5-HTT KO mice. $\boldsymbol{a}$, Neither overall length nor number of IL basilar dendritic branches differed between 5-HTT KO and WT mice. $\boldsymbol{b}$, Genotypes did not differ in amount or distribution of dendritic material. $\boldsymbol{c}$, Neither length nor number of basilar terminal branches was different between genotypes.

drites. Spines were identified based on the morphological criteria for "mushroom" and "thin" spines described by Peters and KaisermanAbramof (1970): only protrusions perpendicular to the dendritic shaft and possessing a clear neck and bulbous head were counted (see Fig. 7a). Because spine density varies with thickness of the dendrite (and therefore branch order), the lengths of dendritic segments were recorded, and spine densities (spines per $10 \mu \mathrm{m}$ ) for each branch order were calculated separately.

Statistical analysis. The effect of genotype on percentage immobility during day 1 forced swim exposure, on percentage freezing during fear conditioning, and on IL and BLA dendrite length and number was ana-
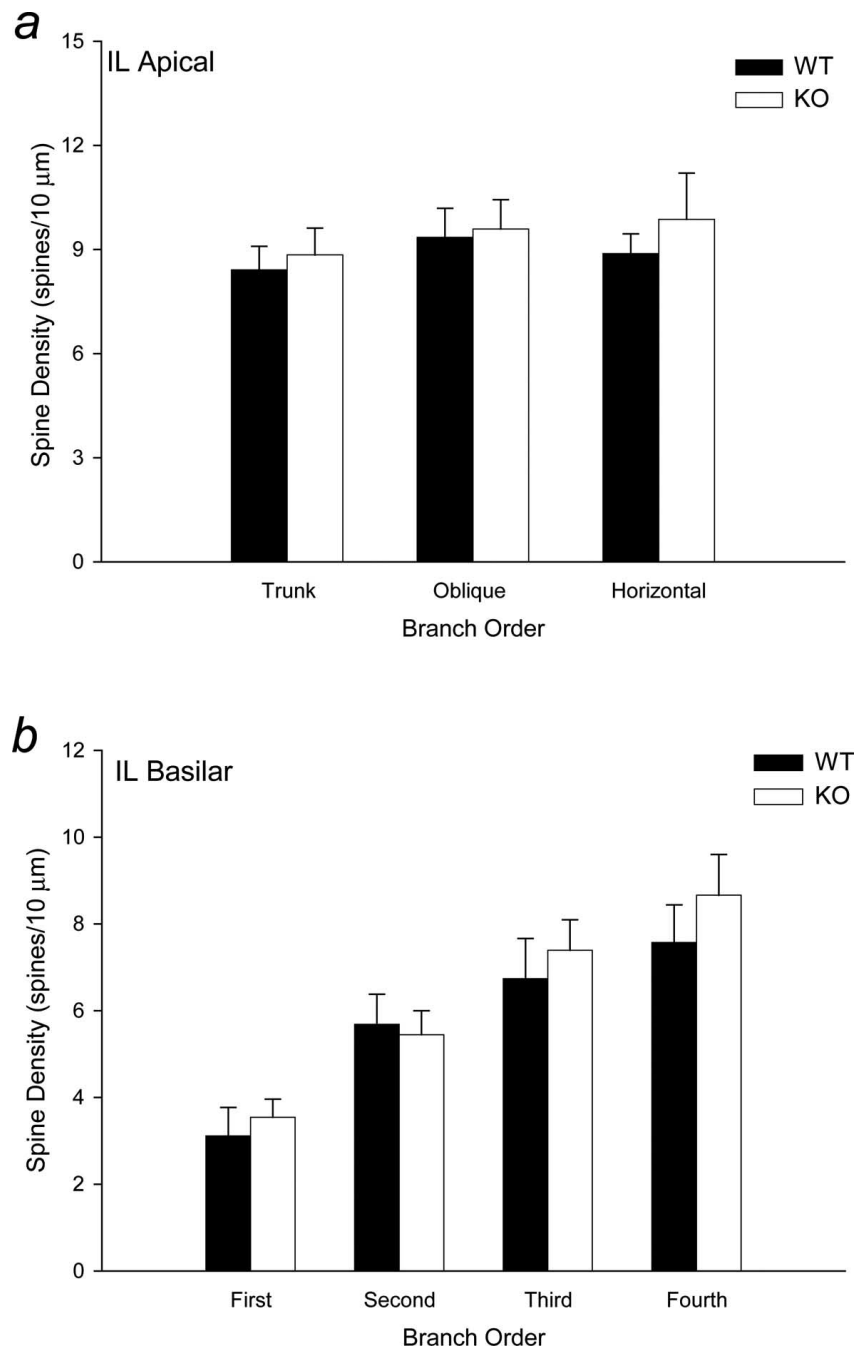

Figure 5. Normal spine density on IL pyramidal neurons in 5-HTT KO mice. Spine density on apical ( $\boldsymbol{a}$ ) and basilar $(\boldsymbol{b})$ dendrites of IL pyramidal neurons did not differ between genotypes.

lyzed using $t$ tests. The effects of genotype $\times$ day 2 forced swim trial number on percentage immobility; the effects of genotype $\times$ CS extinction-trial on percentage freezing; the effects of genotype $\times$ distance from soma on amount and location of dendritic material; and the effects of genotype $\times$ branch order on dendritic spine density were analyzed using two-factor ANOVA with repeated measures. Significant $F$ tests were followed up with Bonferroni comparisons.

\section{Results}

Increased depression-like behavior during repeated stress in 5-HTT KO mice

5-HTT KO mice showed increased behavioral despair after repeated exposure to the forced swim test. Immobility was not different between 5-HTT KO and WT mice during initial exposure $(n s)$. In contrast, on re-exposure to the test $24 \mathrm{~h}$ later, 5-HTT $\mathrm{KO}$ mice showed significantly greater immobility than WT mice $\left(F_{(1,87)}=11.42 ; p<0.01\right)$ (Fig. 1). Generally, there was an increase in immobility with repeated exposure during day 2 $\left(F_{(29,87)}=5.34 ; p<0.01\right)$.

Analysis of the effects of treatment of nonmutant C57BL/6J mice with the reference antidepressant fluoxetine before either day 1 or day 2 forced swim exposure indicated that differences between 5 -HTT KO and WT mice on day 2 but not day 1 of testing were not attributable to poor validity of the modified 
procedure. Fluoxetine produced a significant "antidepressant-like" reduction in immobility in nonmutant $\mathrm{C} 57 \mathrm{BL} / 6 \mathrm{~J}$ regardless of whether mice had been exposed previously to the FST (main effect of dose, $F_{(3,63)}=12.05, p<0.01$; dose $\times$ previous exposure interaction, $n s$ ), whereas immobility was generally lower in mice receiving the first compared with the second exposure $\left(F_{(1,63)}=13.36 ; p<0.01\right)$ (supplemental Table 1, available at www. jneurosci.org as supplemental material).

\section{Impaired extinction recall in 5-HTT KO mice}

5-HTT KO mice exhibited a selective deficit in extinction recall. During conditioning, freezing was not different between 5-HTT KO and WT mice either before, during CS presentation, or immediately after the final CS-US pairing (all $n s$ ). Freezing during initial CS recall (WT, $78.3 \%$; KO, 78.4\% during first trial-block) and extinction was also not different between genotypes ( $n s)$, and both genotypes showed significantly reduced freezing with repeated presentation of the CS $\left(F_{(10,90)}=\right.$ $19.20 ; p<0.01)$. Although there was no significant difference in freezing during extinction, visual inspection of the data indicated higher freezing in 5-HTT KO mice at the end of the session (supplemental Fig. 1, available at www.jneurosci.org as supplemental material). Therefore, to exclude the possibility that any genotype differences in freezing seen during extinction recall were caused by differences in success of extinction learning, rather than recall, genotypes were matched for freezing levels on the final extinction trialblock by excluding three WT and two 5-HTT KO mice from the analysis. Results showed that matching for extinction learning, 5-HTT KO mice exhibited significantly more freezing than WT mice during extinction recall (WT, 54.8\%; KO, 81.9\%) $\left(F_{(1,10)}=\right.$ 5.40; $p<0.05$ ) (Fig. 2). With repeated CS presentations, both WT and 5-HTT KO mice showed significantly reduced freezing $\left(F_{(10,90)}=15.81 ; p<0.01\right)$.

\section{Increased dendritic length in IL, increased spine density in BLA of 5-HTT KO mice}

In IL, overall apical dendritic length was increased by $22 \%$ in 5-HTT KO mice relative to WT controls, and this difference approached significance (Fig. $3 b)\left(t_{9}=2.10 ; p<0.07\right)$. Analysis of the amount and distribution of apical dendritic material confirmed a significant increase in 5-HTT KO mice relative to WT mice $\left(F_{(1,99)}=5.03 ; p<0.05\right)$, which was a result of increased length of terminal branches (Fig. 3$)\left(t_{9}=2.38\right.$; $\left.p<0.05\right)$. In contrast to these morphological changes in apical dendrites, basilar dendrites of IL pyramidal neurons did not differ between genotypes (Fig. 4). In contrast, spine density did not significantly differ between genotypes at any branch order for either apical or basilar dendrites (Fig. $5 a, b$ ) (all $n s$ ).

Dendritic morphology of BLA neurons did not differ significantly between genotypes in overall branch number or length (Fig. $6 a, b$ ), distribution of dendritic material (Fig. 6c), or terminal branch number or length (Fig. $6 d$ ) (all $n s$ ). However, spine density was significantly increased by $24 \%$ in 5 -HTT KO mice
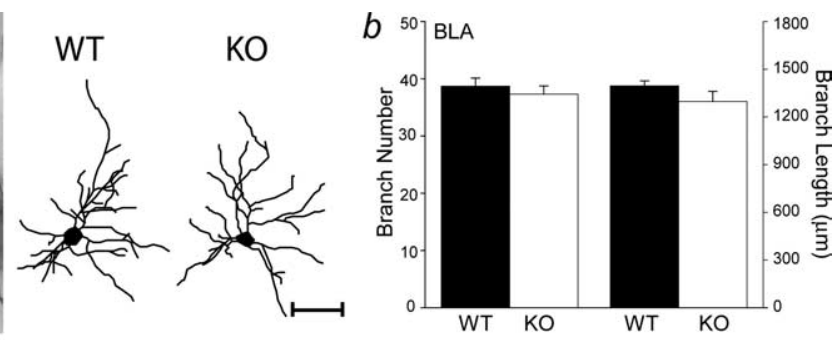

$d$

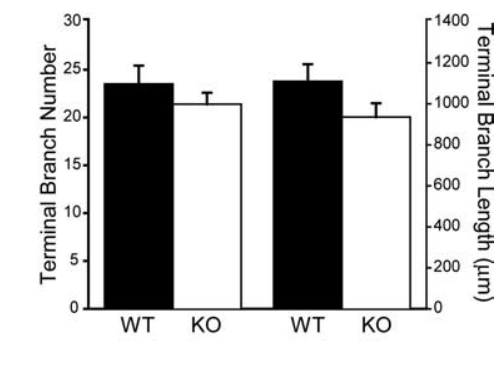

istance from Soma $(\mu \mathrm{m})$

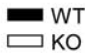

Figure 6. Normal dendritic morphology of BLA pyramidal neurons in 5-HTT K0 mice. $\boldsymbol{a}$, Golgi-stained pyramidal neurons in BLA and computer-assisted reconstructions of representative neurons in WT and 5-HTT KO mice. Scale bars, $50 \mu \mathrm{m}$. $\boldsymbol{b}$, Neither overall length nor number of BLA dendritic branches differed between genotypes. $c$, Genotypes did not differ in amount and distribution of dendritic material. $\boldsymbol{d}$, Neither length nor number of terminal branches was different between genotypes.

relative to WT controls (Fig. 7) $\left(F_{(1,9)}=7.08 ; p<0.05\right)$. Changes in spine density varied across branch orders $\left(F_{(3,27)}=7.01 ; p<\right.$ $0.05)$, with 31 and $61 \%$ increases in spine density on first- and fourth-order branches $\left(t_{9}=9.50\right.$ and 8.86 , respectively; $p<$ $0.05)$.

\section{Discussion}

The present study demonstrates two novel findings. First, genetically driven loss of 5-HTT function produced significant deficits on two measures of responsivity to environmental trauma and stress. Second, these behavioral abnormalities were associated with morphological abnormalities in two key loci of a corticolimbic circuit mediating the processing of emotional stimuli.

5-HTT KO mice exhibited levels of freezing before, during, and immediately after fear conditioning that were similar to WT; demonstrating normal acquisition of associative fear memory in the $\mathrm{KO}$ mice. The fear memory was then extinguished by repeatedly presenting the fear-associated stimulus in the absence of aversive outcome (Pavlov, 1927). During the first session of extinction learning, 5-HTT KO and WT mice exhibited similar progressive reductions in conditioned freezing. In contrast, whereas both genotypes showed an expected spontaneous recovery of the fear response when tested for recall of the extinction memory $24 \mathrm{~h}$ later, the response was markedly higher in 5-HTT $\mathrm{KO}$ mice than in WT mice. 5-HTT KO mice were subsequently able to (re)extinguish to WT levels with additional repeated exposure to the conditioned stimulus. Thus, these data demonstrate a significant and selective impairment in extinction recall in 5-HT KO mice, and extend previous findings that 5-HTT KO mice display increased anxiety-like behaviors, whereas transgenic overexpression of the 5-HTT decreases these behaviors (Ansorge et al., 2004; Hariri and Holmes, 2006; Jennings et al., 2006). A deficit in the ability to acquire or retain extinction memory is a cardinal feature of anxiety disorders such as PTSD (American 

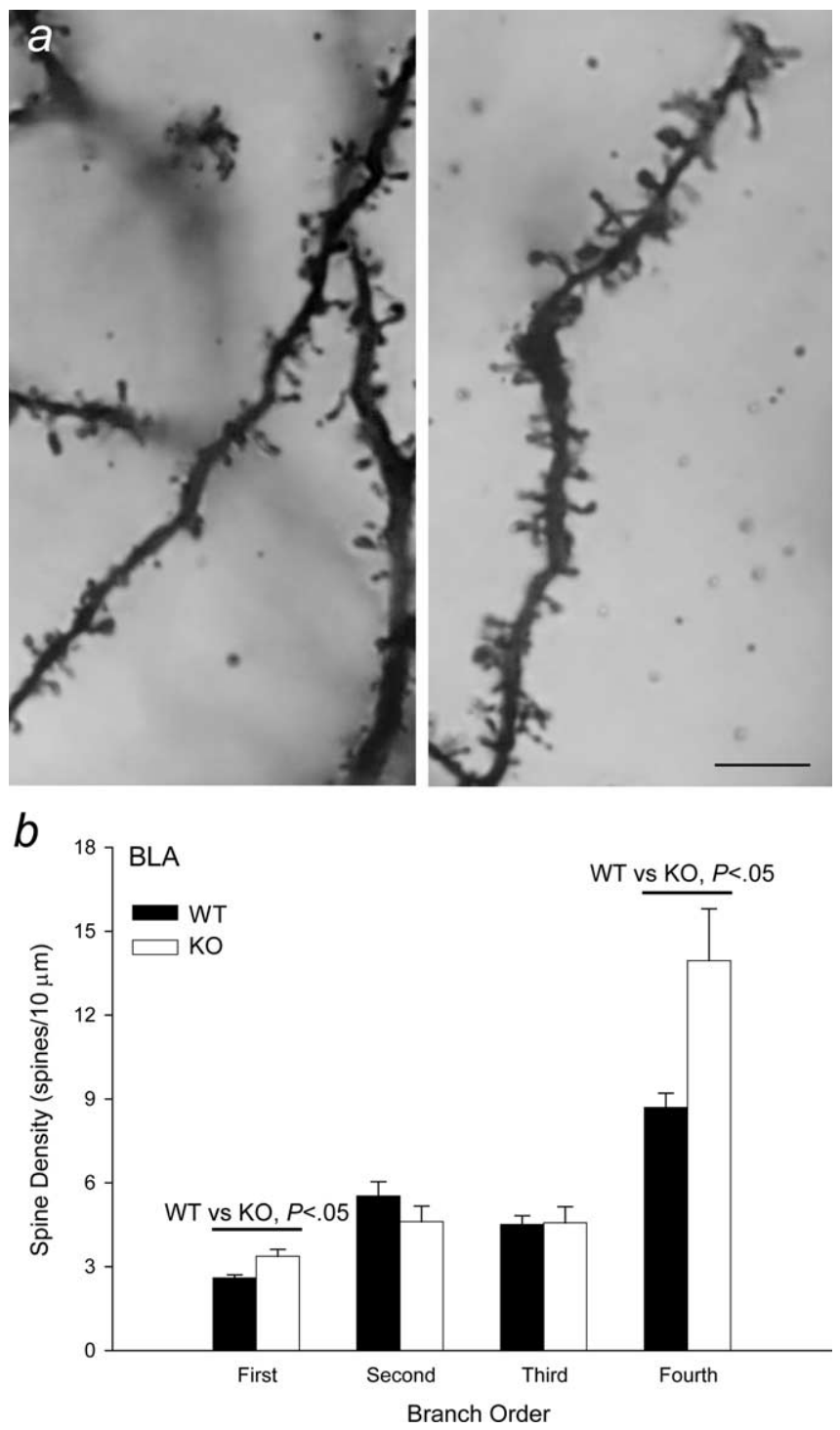

Figure 7. Abnormal spine density on BLA pyramidal neurons in 5-HTT KO mice. $\boldsymbol{a}$, Dendritic spines on a fourth-order branch of a Golgi-stained pyramidal neuron in a WT mouse (left) and a 5-HTT KO mouse (right). Several digital light micrographs were taken at different Z-levels and merged to increase the number of spines in focus. Scale bar, $5 \mu \mathrm{m}$. $\boldsymbol{b}$, Spine density was significantly increased on first- and fourth-order dendrites in 5-HTT KO mice.

Psychiatric Association, 1994). Interestingly, in this context, a recent study found that human beings carrying a low-expressing polymorphic variant of the promoter region of the HTT gene show elevated rates of PTSD (Lee et al., 2005), suggesting that genetically driven loss of 5-HTT function may be a risk factor for the disease.

The human low-expressing variant of the promoter region of the HTT gene has also been associated with heightened risk for major depression in response to exposure to stressful life events and neurochemical challenges such as 5-HT depletion (Neumeister et al., 2002; Caspi and Moffitt, 2006). Similarly, nonhuman primates with an ortholog of the same polymorphism exhibit exaggerated neuroendocrine responses to stress and increased alcohol consumption after being reared under stressful conditions compared with normally reared, but genetically similar, counterparts (Barr et al., 2003). In an interesting parallel with these data, the present study found increased depression-like behavior in 5-HTT KO mice after repeated but not acute exposure to forced swim stress. 5-HTT KO mice also exhibited exaggerated behavioral, neuroendocrine, and catecholamine responses to certain mild stressors such as saline injection or predator exposure that are in themselves insufficiently potent to affect WT mice (Tjurmina et al., 2002; Li et al., 2004; Adamec et al., 2006; Li, 2006). Although parallels between phenotypic data in KO mice and higher species must always be made with due caution (Cryan and Holmes, 2005), together these findings are consistent with a growing literature indicating that loss of 5-HTT gene function compromises the capacity to adaptively cope with environmental stress.

A corpus of data implicates dysfunction of a neural circuit connecting the PFC and amygdala in the pathophysiology of depression and anxiety disorders (Siegle et al., 2002; Phillips et al., 2003; Phelps et al., 2004). Furthermore, recent data from neuroimaging studies indicate that the low-expressing HTT gene variant is associated with functional abnormalities in this circuit, specifically, amygdala hyperactivity coupled with hypofunction in some regions of the PFC (anterior cingulate) and hyperfunction in others (vmPFC) (Hariri et al., 2002; Canli et al., 2005, 2006; Heinz et al., 2005; Pezawas et al., 2005).

The present data indicate morphological abnormalities in both the BLA and vmPFC (IL cortex) of 5-HTT KO mice. First, although gross morphology of pyramidal neurons in the BLA was normal, 5-HTT KO mice had significantly greater spine density on the fourth-order (and therefore likely terminal) BLA dendritic branches of these neurons, relative to WT. Second, whereas spine density was normal in pyramidal neurons in IL of 5-HTT KO mice, the dendrites of these cells were significantly elongated compared with WT mice.

Although these morphological changes do not provide direct evidence of functional alterations in BLA and vmPFC of 5-HTT $\mathrm{KO}$ mice, they provide plausible correlates of neural substrates underlying the behavioral deficits presently observed in these mice. One model is that increased spine density in BLA dendrites may be accompanied by increased excitatory drive of these neurons resulting in amygdala hyperactivity. In turn, via its strong inhibitory input to the amygdala (Canteras et al., 1992; Bacon et al., 1996; McDonald et al., 1996; Quirk et al., 2003; Berretta et al., 2005; Laviolette et al., 2005; Likhtik et al., 2005), increased dendritic extent of IL neurons may be an adaptive response to dampen this hyperactivity.

Alternatively, the primary site of the neural insult could be at the level of the IL rather than the BLA. The specific nature of the behavioral deficits in 5-HTT KO mice would support this hypothesis: the phenotypic profile of increased behavioral despair and poor extinction recall in the $\mathrm{KO}$ mice closely resembles that caused by vmPFC, but not BLA inactivation in rats, and fits with the correlation of IL, but not BLA neuron activity, with successful extinction in rats and humans (Phelps et al., 2004; Amat et al., 2005; Kalisch et al., 2006; Quirk et al., 2006). Moreover, loss of 5-HT clearance in these mice (Daws et al., 2006) produces marked increases in extracellular fluid levels of 5-HT in brain regions, including frontal cortex (Mathews et al., 2004), and recent electrophysiological data indicate that activation of serotonergic input to the medial PFC ( $\mathrm{MPFC}$ ) inhibits the majority of pyramidal neurons therein via $5-\mathrm{HT}_{1 \mathrm{~A}}$ receptors (Hajos et al., 2003; Puig et al., 2005). Thus, the principle consequence of increased extracellular 5-HT in the mPFC of 5-HTT KO mice would likely be to overinhibit vmPFC neuronal activity. Taken from this perspective, the increased dendritic extent in IL of these mice would be consistent with a compensatory effort to restore functional integrity of a hypoactive IL, an effort that, according to 
the present results, is insufficient to normalize fear- and stressrelated deficits. Evidence that differences in the pattern and distribution of cortical neuronal dendrites influences their functional properties (Rall et al., 1992; Mainen and Sejnowksi, 1996; Koch and Segev, 2000), together with the finding that IL morphological alterations in 5-HTT KO were restricted to the terminal branches of apical dendrites that are known to be especially plastic (Cook and Wellman, 2004; Radley et al., 2005; Izquierdo et al., 2006), would fit with a compensatory adaptation to overinhibition.

Although this scheme could potentially account for at least some of the deficits in fear- and stress-related behaviors observed in 5-HTT KO mice, additional studies will be needed to test the model and explore other factors involved. For example, we and others have shown that sensory cortical regions are cytoarchitecturally and functionally abnormal in 5-HTT KO because of excessive 5-HT availability during a critical window of neonatal development (Gaspar et al., 2003; Esaki et al., 2005) and, furthermore, that neonatal disruption of 5-HT or the 5-HTT lead to lifelong abnormalities in mouse anxiety- and stress-related behaviors (Ansorge et al., 2004; Gross and Hen, 2004). This raises the possibility that ontogenic disruption of cortical regions, including vmPFC, may contribute to the fear- and stress-related deficits manifest in 5-HTT KO mice. Another important question for future studies will be whether 5-HTT KO mice have morphological abnormalities in other PFC subregions (e.g., anterior cingulate, prelimbic, and medial orbital cortices) and whether the profile of these mice extends to phenotypic abnormalities associated with dysfunction of these regions in rodents, such as cognitive flexibility and impulse control (Robbins, 2005).

In summary, the present study found that genetically driven loss of 5-HTT function led to deficits in stress-induced depression-related behavior and fear extinction recall that were accompanied by morphological abnormalities in the BLA and vmPFC. These findings support a converging cross-species literature suggesting that relative loss of 5-HTT gene function increases risk for affective disorders by compromising the functional integrity of a key corticolimbic circuit.

\section{References}

Adamec R, Burton P, Blundell J, Murphy DL, Holmes A (2006) Vulnerability to mild predator stress in serotonin transporter knockout mice. Behav Brain Res 170:126-140.

Amat J, Baratta MV, Paul E, Bland ST, Watkins LR, Maier SF (2005) Medial prefrontal cortex determines how stressor controllability affects behavior and dorsal raphe nucleus. Nat Neurosci 8:365-371.

American Psychiatric Association (1994) Diagnostic and statistical manual of mental disorders, Ed 4, pp 424-429. Washington, DC: American Psychiatric Association.

Ansorge MS, Zhou M, Lira A, Hen R, Gingrich JA (2004) Early-life blockade of the 5-HT transporter alters emotional behavior in adult mice. Science 306:879-881.

Arango V, Underwood MD, Mann JJ (2002) Serotonin brain circuits involved in major depression and suicide. Prog Brain Res 136:443-453.

Bacon SJ, Headlam AJN, Gabbott PLA, Smith AD (1996) Amygdala input to medial prefrontal cortex (mPFC) in the rat: a light and electron microscope study. Brain Res 720:211-219.

Ballenger JC (1999) Current treatments of the anxiety disorders in adults. Biol Psychiatry 46:1579-1594.

Barnes NM, Sharp T (1999) A review of central 5-HT receptors and their function. Neuropharmacology 38:1083-1152.

Barr CS, Newman TK, Becker ML, Parker CC, Champoux M, Lesch KP, Goldman D, Suomi SJ, Higley JD (2003) The utility of the non-human primate; model for studying gene by environment interactions in behavioral research. Genes Brain Behav 2:336-340.

Bengel D, Murphy DL, Andrews AM, Wichems CH, Feltner D, Heils A, Moss- ner R, Westphal H, Lesch K-P (1998) Altered brain serotonin homeostasis and locomotor insensitivity to 3,4-methylenedioxymethamphetamine ("ecstasy") in serotonin transporter-deficient mice. Mol Pharmacol 53:649-655.

Berretta S, Pantazopoulos H, Caldera M, Pantazopoulos P, Paré D (2005) Infralimbic cortex activation increases $\mathrm{C}$-Fos expression in intercalated neurons of the amygdala. Neuroscience 132:943-953.

Blakely RD, Berson HE, Fremeau Jr RT, Caron MG, Peek MM, Prince HK, Bradley CC (1991) Cloning and expression of a functional serotonin transporter from rat brain. Nature 354:66-70.

Boyce-Rustay JM, Holmes A (2006) Genetic inactivation of the NMDA receptor NR2A subunit has anxiolytic- and antidepressant-like effects in mice. Neuropsychopharmacology 31:2405-2414.

Cain CK, Blouin AM, Barad M (2002) L-type voltage-gated calcium channels are required for extinction, but not for acquisition or expression, of conditional fear in mice. J Neurosci 22:9113-9121.

Canli T, Omura K, Haas BW, Fallgatter A, Constable RT, Lesch KP (2005) Beyond affect: a role for genetic variation of the serotonin transporter in neural activation during a cognitive attention task. Proc Natl Acad Sci USA 102:12224-12229.

Canli T, Qiu M, Omura K, Congdon E, Haas BW, Amin Z, Herrmann MJ, Constable RT, Lesch KP (2006) Neural correlates of epigenesis. Proc Natl Acad Sci USA 103:16033-16038.

Canteras NS, Simerly RB, Swanson LW (1992) Connections of the posterior nucleus of the amygdala. J Comp Neurol 324:143-179.

Caspi A, Moffitt TE (2006) Gene-environment interactions in psychiatry: joining forces with neuroscience. Nat Rev Neurosci 7:583-590.

Cook SC, Wellman CL (2004) Chronic stress alters dendritic morphology in rat medial prefrontal cortex. J Neurobiol 60:236-248.

Cryan JF, Holmes A (2005) The ascent of mouse: advances in modelling human depression and anxiety. Nat Rev Drug Discov 4:775-790.

Daws LC, Montanez S, Munn JL, Owen AM, Baganz NL, Boyce-Rustay J, Millstein RA, Wiedholz L, Murphy DL, Holmes A (2006) Ethanol inhibits clearance of brain serotonin by a serotonin transporter-independent mechanism. J Neurosci

Esaki T, Cook M, Shimoji K, Murphy DL, Sokoloff L, Holmes A (2005) Developmental disruption of serotonin transporter function impairs cerebral responses to whisker stimulation in mice. Proc Natl Acad Sci USA 102:5582-5587.

Garpenstrand H, Annas P, Ekblom J, Oreland L, Fredrikson M (2001) Human fear conditioning is related to dopaminergic and serotonergic biological markers. Behav Neurosci 115:358-364.

Gaspar P, Cases O, Maroteaux L (2003) The developmental role of serotonin: news from mouse molecular genetics. Nat Rev Neurosci 4:1002-1012.

Glaser EM, Van der Loos H (1981) Analysis of thick brain sections by obverse-reverse computer microscopy: application of a new, high-quality Golgi-Nissl stain. J Neurosci Methods 4:117-125.

Gross C, Hen R (2004) The developmental origins of anxiety. Nat Rev Neurosci 5:545-552.

Hajos M, Gartside SE, Varga V, Sharp T (2003) In vivo inhibition of neuronal activity in the rat ventromedial prefrontal cortex by midbrain-raphe nuclei: role of 5-HT1A receptors. Neuropharmacology 45:72-81.

Hariri AR, Holmes A (2006) Genetics of emotional regulation: the role of the serotonin transporter in neural function. Trends Cogn Sci 10:182-191.

Hariri AR, Mattay VS, Tessitore A, Kolachana B, Fera F, Goldman D, Egan MF, Weinberger DR (2002) Serotonin transporter genetic variation and the response of the human amygdala. Science 297:400-403.

Heinz A, Braus DF, Smolka MN, Wrase J, Puls I, Hermann D, Klein S, Grusser SM, Flor H, Schumann G, Mann K, Buchel C (2005) Amygdalaprefrontal coupling depends on a genetic variation of the serotonin transporter. Nat Neurosci 8:20-21.

Holmes A, Yang RJ, Murphy DL, Crawley JN (2002) Evaluation of antidepressant-related behavioral responses in mice lacking the serotonin transporter. Neuropsychopharmacology 27:914-923.

Izquierdo A, Wellman CL, Holmes A (2006) Brief uncontrollable stress causes dendritic retraction in infralimbic cortex and resistance to fear extinction in mice. J Neurosci 26:5733-5738.

Jennings KA, Loder MK, Sheward WJ, Pei Q, Deacon RM, Benson MA, Olverman HJ, Hastie ND, Harmar AJ, Shen S, Sharp T (2006) Increased ex- 
pression of the 5-HT transporter confers a low-anxiety phenotype linked to decreased 5-HT transmission. J Neurosci 26:8955-8964.

Kalisch R, Korenfeld E, Stephan KE, Weiskopf N, Seymour B, Dolan RJ (2006) Context-dependent human extinction memory is mediated by a ventromedial prefrontal and hippocampal network. J Neurosci 26:9503-9511.

Koch C, Segev I (2000) The role of single neurons in information processing. Nat Neurosci 3:1171-1177.

Larkman AU (1991) Dendritic morphology of pyramidal neurones of the visual cortex of the rat: I. Branching patterns. J Comp Neurol 306:307-319.

Laviolette SR, Lipski WJ, Grace AA (2005) A subpopulation of neurons in the medial prefrontal cortex encodes emotional learning with burst and frequency codes through a dopamine $\mathrm{D}_{4}$ receptor-dependent basolateral amygdala input. J Neurosci 25:6066-6075.

Lee HJ, Lee MS, Kang RH, Kim H, Kim SD, Kee BS, Kim YH, Kim YK, Kim JB, Yeon BK, Oh KS, Oh BH, Yoon JS, Lee C, Jung HY, Chee IS, Paik IH (2005) Influence of the serotonin transporter promoter gene polymorphism on susceptibility to posttraumatic stress disorder. Depress Anxiety 21:135-139.

Lesch K-P, Bengel D, Heils A, Sabol SZ, Greenberg BD, Petri S, Benjamin J, Muller CR, Hamer DH, Murphy DL (1996) Association of anxietyrelated traits with a polymorphism in the serotonin transporter gene regulatory region. Science 274:1527-1531.

Li Q (2006) Cellular and molecular alterations in mice with deficient and reduced serotonin transporters. Mol Neurobiol 34:51-66.

Li Q, Holmes A, Ma L, Van de Kar LD, Garcia F, Murphy DL (2004) Medial hypothalamic 5-hydroxytryptamine (5-HT)1A receptors regulate neuroendocrine responses to stress and exploratory locomotor activity: application of recombinant adenovirus containing $5-\mathrm{HT}_{1 \mathrm{~A}}$ sequences. J Neurosci 24:10868-10877.

Likhtik E, Pelletier JG, Paz R, Pare D (2005) Prefrontal control of the amygdala. J Neurosci 25:7429-7437.

Mainen ZF, Sejnowksi TJ (1996) Influence of dendritic structure on firing pattern in model neocortical neurons. Nature 382:363-366.

Mathews TA, Fedele DE, Coppelli FM, Avila AM, Murphy DL, Andrews AM (2004) Gene dose-dependent alterations in extraneuronal serotonin but not dopamine in mice with reduced serotonin transporter expression. J Neurosci Methods 140:169-181.

McDonald AJ, Mascagni F, Guo L (1996) Projections of the medial and lateral prefrontal cortices to the amygdala: a Phaseolus vulgaris leucoagglutinin study in the rat. Neuroscience 71:55-75.

Milad MR, Quirk GJ (2002) Neurons in medial prefrontal cortex signal memory for fear extinction. Nature 420:70-74.

Miracle AD, Brace MF, Huyck KD, Singler SA, Wellman CL (2006) Chronic stress impairs recall of extinction of conditioned fear. Neurobiol Learn Mem 85:213-218.

Munafo MR, Clark T, Flint J (2005) Does measurement instrument moderate the association between the serotonin transporter gene and anxietyrelated personality traits? A meta-analysis. Mol Psychiatry 10:415-419.

Neumeister A, Konstantinidis A, Stastny J, Schwarz MJ, Vitouch O, Willeit M, Praschak-Rieder N, Zach J, de Zwaan M, Bondy B, Ackenheil M, Kasper S (2002) Association between serotonin transporter gene promoter polymorphism (5HTTLPR) and behavioral responses to tryptophan depletion in healthy women with and without family history of depression. Arch Gen Psychiatry 59:613-620.

Pavlov IP (1927) Conditioned reflexes. London: Oxford UP.

Paxinos G, Franklin KBJ (2001) The mouse brain in stereotaxic coordinates, Ed 2. San Diego: Academic.
Peters A, Kaiserman-Abramof IR (1970) The small pyramidal neuron of the rat cerebral cortex. The perikaryon, dendrites and spines. Am J Anat 127:321-355.

Pezawas L, Meyer-Lindenberg A, Drabant EM, Verchinski BA, Munoz KE, Kolachana BS, Egan MF, Mattay VS, Hariri AR, Weinberger DR (2005) 5-HTTLPR polymorphism impacts human cingulate-amygdala interactions: a genetic susceptibility mechanism of depression. Nat Neurosci 8:828-834.

Phelps EA, Delgado MR, Nearing KI, LeDoux JE (2004) Extinction learning in humans: role of the amygdala and vmPFC. Neuron 43:897-905.

Phillips ML, Drevets WC, Rauch SL, Lane R (2003) Neurobiology of emotion perception II: implications for major psychiatric disorders. Biol Psychiatry 54:515-528.

Porsolt RD, Le Pichon M, Jalfre M (1977) Depression: a new animal model sensitive to antidepressant treatments. Nature 266:730-732.

Puig MV, Artigas F, Celada P (2005) Modulation of the activity of pyramidal neurons in rat prefrontal cortex by raphe stimulation in vivo: involvement of serotonin and GABA. Cereb Cortex 15:1-14.

Quirk GJ, Beer JS (2006) Prefrontal involvement in the regulation of emotion: convergence of rat and human studies. Curr Opin Neurobiol 16:723-727.

Quirk GJ, Russo GK, Barron JL, Lebron K (2000) The role of ventromedial prefrontal cortex in the recovery of extinguished fear. J Neurosci 20:6225-6231.

Quirk GJ, Likhtik E, Pelletier JG, Pare D (2003) Stimulation of medial prefrontal cortex decreases the responsiveness of central amygdala output neurons. J Neurosci 23:8800-8807.

Quirk GJ, Garcia R, Gonzalez-Lima F (2006) Prefrontal mechanisms in extinction of conditioned fear. Biol Psychiatry 60:337-343.

Radley JJ, Rocher AB, Miller M, Janssen WG, Liston C, Hof PR, McEwen BS, Morrison JH (2005) Repeated stress induces dendritic spine loss in the rat medial prefrontal cortex. Cereb Cortex 16:313-320.

Rall W, Burke RE, Holmes WR, Jack JJ, Redman SJ, Segev I (1992) Matching dendritic neuron models to experimental data. Physiol Rev 72:S159-S186.

Robbins TW (2005) Chemistry of the mind: neurochemical modulation of prefrontal cortical function. J Comp Neurol 493:140-146.

Santini E, Muller RU, Quirk GJ (2001) Consolidation of extinction learning involves transfer from NMDA-independent to NMDA-dependent memory. J Neurosci 21:9009-9017.

Santini E, Ge H, Ren K, de Ortiz SP, Quirk GJ (2004) Consolidation of fear extinction requires protein synthesis in the medial prefrontal cortex. J Neurosci 24:5704-5710.

Siegle GJ, Steinhauer SR, Thase ME, Stenger VA, Carter CS (2002) Can't shake that feeling: event-related fMRI assessment of sustained amygdala activity in response to emotional information in depressed individuals. Biol Psychiatry 51:693-707.

Smith Y, Pare JF, Pare D (2000) Differential innervation of parvalbuminimmunoreactive interneurons of the basolateral amygdaloid complex by cortical and intrinsic inputs. J Comp Neurol 416:496-508.

Sotres-Bayon F, Bush DEA, LeDoux JE (2004) Emotional perseveration: an update on prefrontal-amygdala interactions in fear extinction. Learn Mem 11:525-535.

Tjurmina OA, Armando I, Saavedra JM, Goldstein DS, Murphy DL (2002) Exaggerated adrenomedullary response to immobilization in mice with targeted disruption of the serotonin transporter gene. Endocrinology 143: $4520-4526$. 